\title{
REVIEW
}

\section{Signaling regulation of fetoplacental angiogenesis}

\author{
Kai Wang and Jing Zheng ${ }^{1}$ \\ Clinical and Translational Research Center, Shanghai First Maternity and Infant Hospital, Tongji University School of Medicine, Shanghai 200040, China \\ ${ }^{1}$ Perinatal Research Laboratories, Department of Obstetrics and Gynecology, University of Wisconsin, PAB1 Meriter Hospital, 202 South Park Street, \\ Madison, Wisconsin 53715, USA \\ (Correspondence should be addressed to J Zheng; Email: jzheng@wisc.edu)
}

\begin{abstract}
During normal pregnancy, dramatically increased placental blood flow is critical for fetal growth and survival as well as neonatal birth weights and survivability. This increased blood flow results from angiogenesis, vasodilatation, and vascular remodeling. Locally produced growth factors including fibroblast growth factor 2 (FGF2) and vascular endothelial growth factor A (VEGFA) are key regulators of placental endothelial functions including cell proliferation, migration, and vasodilatation. However, the precise signaling mechanisms underlying such regulation in fetoplacental endothelium are less well defined, specifically with regard
\end{abstract}

to the interactions amongst protein kinases (PKs), protein phosphatase, and nitric oxide (NO). Recently, we and other researchers have obtained solid evidence showing that different signaling mechanisms participate in FGF2- and VEGFA-regulated fetoplacental endothelial cell proliferation and migration as well as NO production. This review will briefly summarize currently available data on signaling mediating fetoplacental angiogenesis with a specific emphasis on PKs, ERK1/2, AKT1, and p38 MAPK and protein phosphatases, PPP2 and PPP3.

Journal of Endocrinology (2012) 212, 243-255

\section{Introduction}

During normal pregnancy, dramatically increased feto- and utero-placental blood flows are highly correlated with fetal growth and survival as well as neonatal birth weights and survivability (Alexander 1974, Rosenfeld et al. 1974, Reynolds \& Redmer 1995, Reynolds et al. 2005). These increased blood flows are primarily caused by angiogenesis, vasodilatation, and vascular remodeling (Barcroft \& Barron 1946, Magness \& Zheng 1996, Osol \& Mandala 2009). Two potent angiogenic factors, fibroblast growth factor 2 (FGF2) and vascular endothelial growth factor A (VEGFA), are key factors regulating placental vascular growth, vasodilatation, and vascular remodeling (Klagsbrun \& D'Amore 1991, Ferrara et al. 2003, Osol \& Mandala 2009). Local endothelial production of vasodilators such as nitric oxide (NO) is increased during pregnancy in temporal association with increases in the production of placental angiogenic factors and may play an active role in the integral regulation of placental angiogenesis and vasodilatation (Myatt 1992, Magness \& Zheng 1996, Sladek et al. 1997, Magness 1998, Szukiewicz et al. 2005, Brownbill et al. 2007, Sprague et al. 2010).

FGF2 is one of the most extensively studied members in FGF family, which consists of at least nine structurally related polypeptides (Klein et al. 1997, Powers et al. 2000). Not only is FGF2 expressed in endothelial cells but also it is thought to act as an autocrine factor. However, it is still not fully understood how FGF2 is released from the cells. The cellular response to FGF2 is mediated by binding and activating its high-affinity receptors that have cytoplasmic tyrosine kinase domains. Similar to FGF2, VEGFA is also a member of a family of structurally homologous growth factors with a potent angiogenic activity for vascular endothelial cells (Ferrara et al. 2003). Biological actions of VEGFA are initiated upon binding to its highaffinity receptors including VEGFR1 (Flt1) and VEGFR2 (Flk1/KDR; Gille et al. 2000, Ferrara et al. 2003). VEGFR2 is the major signal transducer of VEGFA, responsible for mediating VEGFA-stimulated major steps of angiogenesis (endothelial cell proliferation and migration) and vasodilatation, whereas VEGFR1 may inhibit VEGFR2-mediated endothelial functions (Gille et al. 2000, Ferrara et al. 2003). However, knocking down either of these receptors in the mouse impairs vascular growth and development during the early embryonic stage, ultimately leading to embryonic death, indicating that both VEGFR1 and VEGFR2 are important for vascular formation and growth during early embryonic stage (Fong et al. 1995, Shalaby et al. 1995). 
Over the past decade, it has become clear that in addition to its vasodilatory activity, $\mathrm{NO}$ serves as a downstream signaling mediating FGF2- and VEGFA-stimulated angiogenesis (Ziche et al. 1993, 1994, 1997a,b, Arnal et al. 1996, Noiri et al. 1997, Babaei et al. 1998, Murohara et al. 1998, Fulton et al. 1999, Morales-Ruiz et al. 2000). However, it is still not well defined what the signaling pathways are participating in FGF2- and VEGFA-promoted placental angiogenesis and how NO modulates placental angiogenesis.

\section{In vitro cell models}

As significant improvements in methodology have occurred over the past two decades (Manjunath et al. 2009, Morris 2009), it has become possible to analyze the roles of individual signaling molecule in vivo. For example, it is now possible to specifically knock down an individual signaling component in a selected tissue or cell type beyond the embryonic stage using lentivirus-mediated RNA interference in vivo. However, owing to the complexity of signaling networks and technical difficulties, it is still extremely challenging to dissect individual signaling induced by a single factor in tissues and cells in vivo, specifically since the same signaling pathway could be activated simultaneously by a number of humoral (i.e. steroid hormone and peptide growth factors; Klein et al. 1997, Powers et al. 2000) and physical factors (i.e. shear stress and circumferential stress; Li et al. 2003, 2004, Osol \& Mandala 2009, Sprague et al. 2009, 2010). Hence, most of our current knowledge on signaling mechanisms governing placental endothelial cell functions has been built on in vitro cell models.

It is well established that under normal physiological states, angiogenesis in vivo primarily occurs in microvasculature consisting of arterioles, capillaries, and venules, suggesting that endothelial cells isolated from these microvascular beds are the best cell models for studying placental angiogenesis. Indeed, over the last two decades, great efforts have been made to obtain microvascular endothelial cells from human placentas (Challier et al. 1995, Kacemi et al. 1997, Ugele \& Lange 2001, Lang et al. 2003, Wang et al. 2003, Dye et al. 2004). These placental micro- and macrovascular (i.e. human umbilical and chorionic plate arteries and veins) endothelial cells differ in their embryological origins. For example, the villous capillary endothelia are generated de novo from mesodermally derived hemangioblastic cells in early placental villi, and the chorionic plate artery endothelia are derived from allantoic vessels in the connecting stack during early embryonic stage (Benirschke et al. 2006a,b, Wang \& Zhao 2010). In addition, these placental microvascular endothelial cells could differ significantly from those generated from macrovessels (i.e. human umbilical veins) in their morphologies and in their responses to certain growth factors such as placental growth factor, but not to others such as FGF2 and VEGFA (Lang et al. 2003). These placental microvascular endothelial cells reportedly were enriched either from digesting enzyme effluents perfused through placentas via a chorionic artery (Lang et al. 2003) or from enzyme solutions applied to digest placental tissues or terminal villous vessels (Challier et al. 1995, Kacemi et al. 1997, Ugele \& Lange 2001, Wang et al. 2003, Dye et al. 2004). These cell preparations, however, were inevitably composed of mixed populations of endothelial cells from both macroand microvasculatures, possibly including all three types of microvasculatures (arterioles, capillaries, and venules). Specifically, the exact origin of these endothelial cells was hard to confirm due to the lack of specific markers for identifying or separating macro- or micro-vascular endothelium or each individual microvascular endothelium. Given the fact that different origins of endothelia are highly heterogeneous in global gene expression profiles, possibly leading to different cell phenotypes including morphologies, growth rates, and responses to stimuli (Chi et al. 2003, Lang et al. 2003, 2008, Aitsebaomo et al. 2008, dela Paz \& D'Amore 2009, Rocha \& Adams 2009), it is still questionable whether these mixed populations of cells can closely represent overall phenotypes of placental endothelial cells in vivo, especially after extensive expansion in vitro, during which cells derived from a specific locus are likely to become dominant.

On the other hand, endothelial cells isolated from relatively larger vessels, particularly placental arteries and veins (Zheng et al. 2005, Lang et al. 2008, Wang et al. 2009) as well as umbilical cord vessels (Chi et al. 2003) have been widely used for studying human endothelial functions because of their technical feasibility for obtaining a large number of cells with a high purity from a single type of vessel (Baudin et al. 2007). Since the cell proliferative responses to FGF2 and VEGFA were similar between endothelial cells isolated from the placental microvasculature and human umbilical veins (Lang et al. 2003), endothelial cells from those large vessels could be used as cell models for studying placental endothelial functions at least in regard to actions of FGF2 and VEGFA. Indeed, much of our current knowledge of regulation of human endothelial functions and signaling mechanisms has been obtained from these endothelial cell models.

\section{Protein kinases}

The cellular responses to FGF2 and VEGFA are mediated by activating their specific receptors that have cytoplasmic tyrosine kinase domains. Upon activation, these receptortyrosine kinases initiate a cascade of cellular protein phosphorylation by protein kinases (PKs), including ERK1/2, AKT1, and p38 MAPK (Cobb 1999, Boilly et al. 2000, Gille et al. 2000, Powers et al. 2000, Cross et al. 2003). ERK1/2, a threonine and tyrosine kinase, is phosphorylated and activated predominantly by MEK $1 / 2$ in the cytosol, translocates to the nucleus, and subsequently stimulates transcription of early response genes (Davis 1993, Blumer \& Johnson 1994). AKT1 (also referred to as PKB) is a serine and threonine kinase, which is one major downstream target of PI3K. The MEK1/2/ERK1/2 and the PI3K/AKT1 signaling pathways are heavily involved in regulation of cell survival, 
A
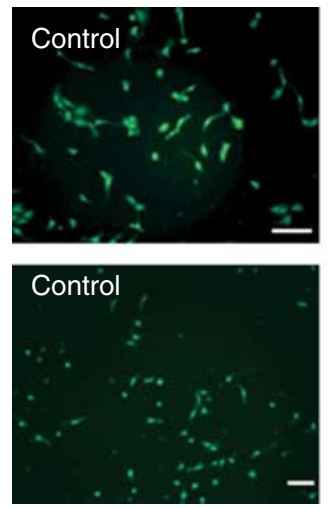

Represent images of OFPAE cell migration
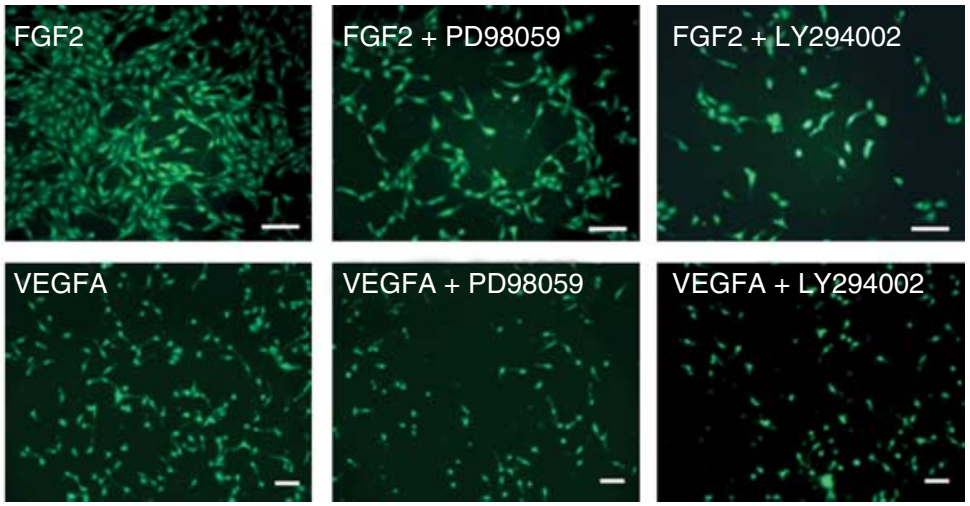

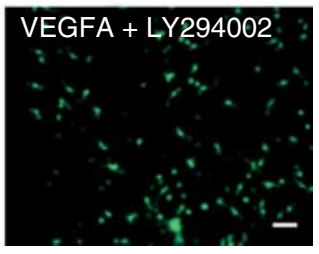

B

Quantitative analysis for OFPAE cell migration
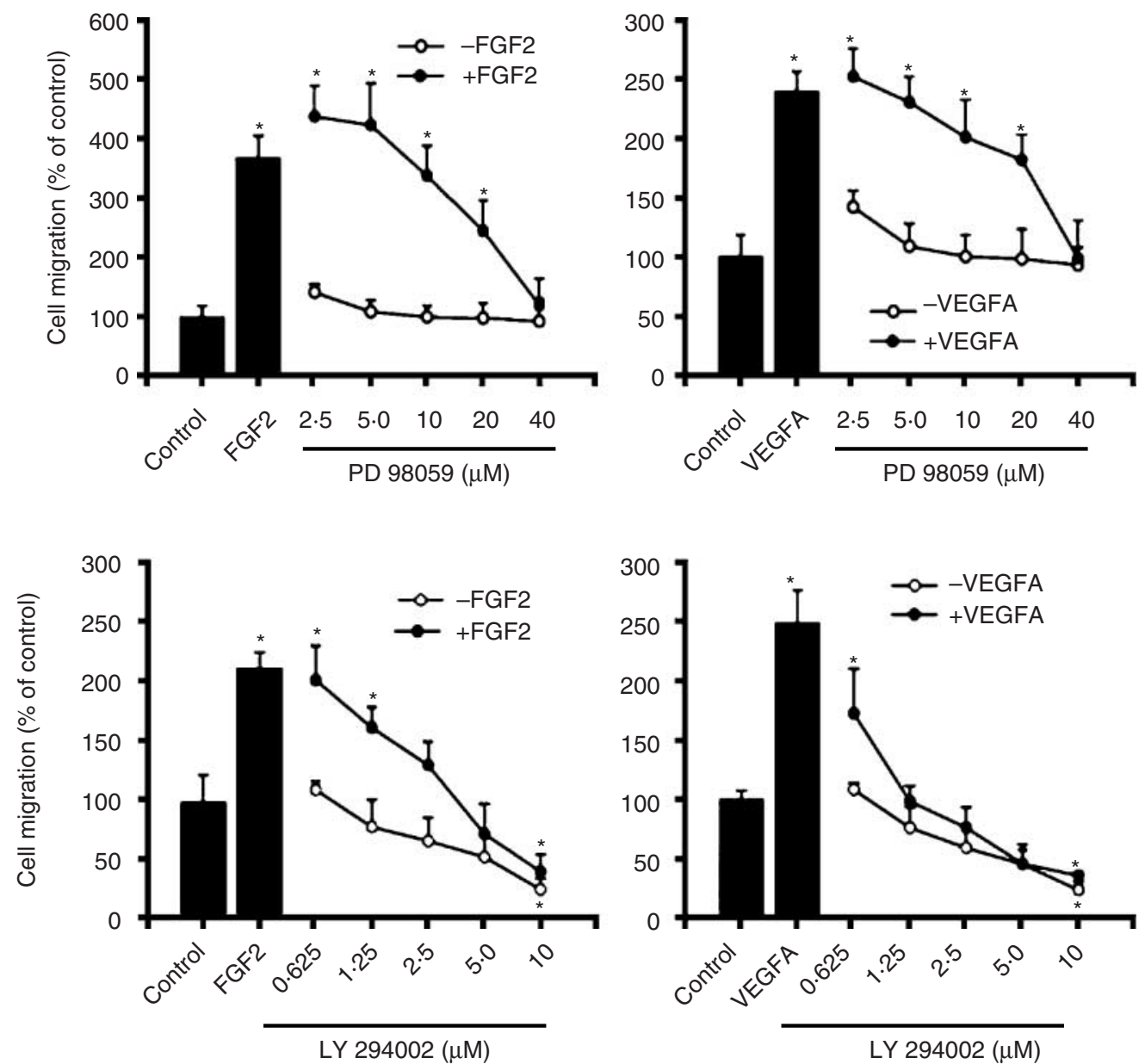

Figure 1 Effects of PD98059 and LY294002 on FGF2- and VEGFA-stimulated OFPAE cell migration. Cell migration was measured using a Multiwell BD Falcon FluoroBlok Insert System $(8 \cdot 0 \mu \mathrm{m}$ pores, BD Biosciences, San Jose, CA, USA). Cells were treated with $10 \mathrm{ng} / \mathrm{ml}$ of FGF2 or VEGFA in the absence or presence of PD98059 or LY294002 (1 h of pretreatment). Cells were counted after $16 \mathrm{~h}$ of treatment. (A) Representative images are shown, in which concentrations of PD98059 and LY294002 were at 40 and $6 \mu \mathrm{M}$ respectively. Bar $=100 \mu \mathrm{m}$. (B) Data are expressed as means \pm S.E.M. percentage of the controls. All data were analyzed using one-way ANOVA. When an $F$ test was significant, data were compared with the control by Bonferroni's multiple comparisons or Student's $t$-test. *Significantly different from the control $(n=5 ; P \leq 0 \cdot 05)$. 
proliferation, and migration (Rousseau et al. 1997, Cobb 1999, Boilly et al. 2000, Gille et al. 2000, Powers et al. 2000, Vivanco \& Sawyers 2002). p38 MAPK is also a serine and threonine kinase comprising at least four isoforms, $\alpha, \beta, \gamma$, and $\delta$, and is activated predominantly by MEK3/6. p38 MAPK $\alpha, \beta$, and $\delta$ isoforms are ubiquitously expressed, whereas p38 $\gamma$ appears to be specially expressed in skeletal muscle. Activation of p38 MAPK was initially considered to be induced by environmental stress and inflammatory cytokines (Kyriakis \& Avruch 1996); however, increasing evidence has shown that p38 MAPK also participates in growth factor-regulated cell functions including growth and migration (Boilly et al. 2000, Cross et al. 2003).

Activation of the ERK1/2, AKT1, and p38 MAPK is well known to play a critical role in FGF2- and VEGFAstimulated endothelial cell proliferation and differentiation (Sa et al. 1995, D’Angelo et al. 1995, Matsumoto et al. 2002). However, the integration of these different kinases is extremely complicated in endothelium. It has been shown that activation of both ERK1/2 and PI3K is required for inducing a complete cell proliferation in response to FGF2, but not VEGFA in bovine choroidal endothelial cells (Zubilewicz et al. 2001). Similarly, activation of both ERK1/2 and p38 MAPK was also needed to induce FGF2stimulated cell proliferation and migration in mouse spleen endothelial cells (Tanaka et al. 1999). These data suggest important mediation of parallel activation of both ERK1/2/ PI3K and ERK1/2/p38 MAPK in growth factor-induced angiogenesis. On the other hand, inhibition of p38 MAPK has been shown to enhance VEGFA-induced angiogenesis, accompanied by prolonged ERK1/2 activation in human lung-derived microvascular endothelial (HLDME) cells (Issbrucker et al. 2003). Inhibition of p38 MAPK also promoted VEGFA-promoted endothelial cell survival, partially via enhancing activation of the PI3K/AKT1 pathway in bovine aortic endothelial (BAE) and human umbilical cord vein epithelial (HUVE) cells (Gratton et al. 2001). Thus, an antagonistic regulation between p38 MAPK and ERK1/2 or AKT1 may also be important for endothelial functions including angiogenesis.

In ovine fetal placental artery endothelial (OFPAE) cells that were derived from secondary and tertiary branches of umbilical cords of late pregnant ewes (Zheng et al. 2005), both FGF2 and VEGFA robustly induced activation of the ERK1/2, AKT1, and p38 MAPK pathways, which at least partially mediated FGF2- and VEGFA-stimulated cell proliferation and migration (Zheng et al. 1999, 2008, Wang et al. 2008, 2009, Liao et al. 2009, 2010, Song et al. 2009, Figs 1 and 2). Intriguingly, the MEK $1 / 2 / \mathrm{ERK} 1 / 2$ and/or PI3K/AKT1 pathways differentially mediated the FGF2and VEGFA-stimulated OFPAE cell proliferation and migration (Zheng et al. 2008, Figs 1 and 2). For example, inhibition of either the MEK1/2/ERK1/2 or PI3K/AKT1 pathway only partially attenuated the FGF2-stimulated cell proliferation, whereas it completely blocked the VEGFA-stimulated cell proliferation as well as the VEGFA-
A
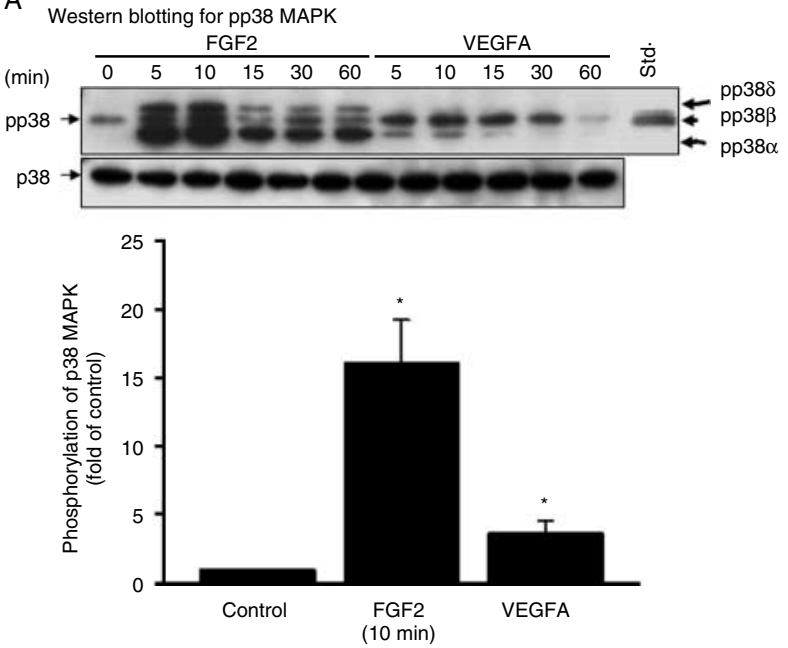

B SB203580 inhibits FGF2-induced cell proliferation and migration
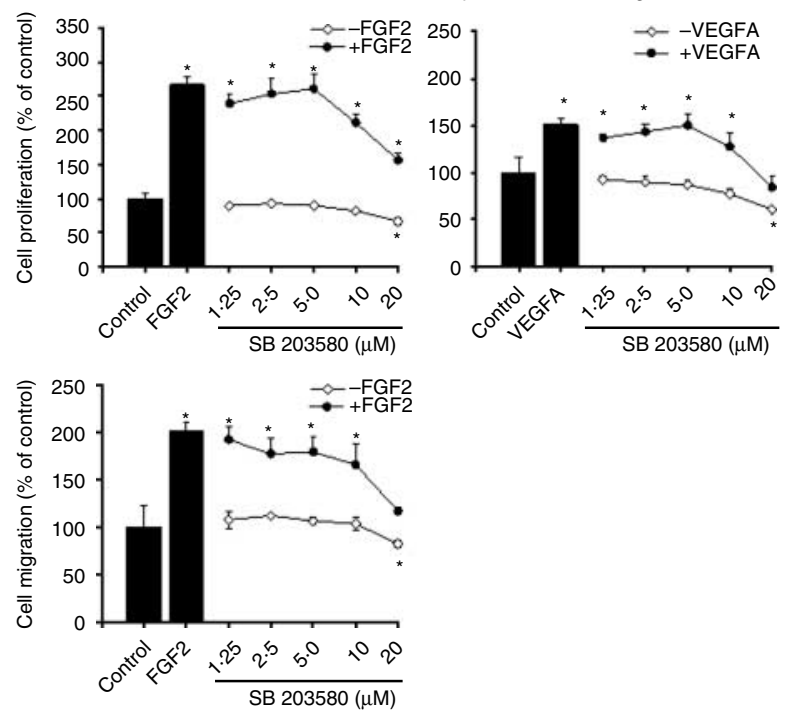

Figure 2 Effects of SB203580 on FGF2- and VEGFA-stimulated cell proliferation and FGF2-stimulated cell migration in OFPAE cells. (A) A time course for FGF2- and VEGFA-induced phosphorylation of p38 MAPK. Note: 1) Both FGF2 and VEGFA $(10 \mathrm{ng} / \mathrm{ml})$ rapidly $(\sim 10 \mathrm{~min})$ induced $(P \leq 0 \cdot 05)$ overall p38 MAPK phosphorylation; 2) FGF2 appeared to be much more potent in inducing p38 MAPK phosphorylation compared with VEGFA; and 3) FGF2 and VEGFA did not significantly alter protein levels of total p38 MAPK (p38). Data shown were collected after 10 min of FGF2 and VEGFA stimulation, pooled from all three p38 MAPK isoforms, and analyzed as described earlier. Data normalized to total p38 are expressed as means \pm s.E.M. fold of the controls. *Significantly different from the control $(n=5 ; P \leq 0 \cdot 05)$. (B) Effects of SB203580 on OFPAE cell proliferation and migration. Cell proliferation assay was carried out using a crystal violet method. Cells were treated with $10 \mathrm{ng} / \mathrm{ml}$ of FGF2 or VEGFA in the absence or presence of SB203580 ( $1 \mathrm{~h}$ of pretreatment). Cells were counted after 72 or $16 \mathrm{~h}$ of treatments, respectively, for cell proliferation and migration assays. 
and FGF2-stimulated cell migration (Zheng et al. 2008, Fig. 1). Similarly, inhibition of p38 MAPK moderately suppressed the FGF2-stimulated cell proliferation and migration (Fig. 2), whereas it did not alter VEGFA-stimulated cell proliferation (Fig. 2) and migration (Liao et al. 2009, 2010). In addition, inhibition of MEK1/2 by PD98059 (a selective MEK inhibitor) significantly decreased FGF2- and VEGFA-induced p38 MAPK, but not AKT1 phosphorylation, whereas LY294002 (a selective PI3K inhibitor) and SB203580 (a selective p38 MAPK inhibitor) did not appear to alter ERK1/2 phosphorylation (Fig. 3). These observations suggest that activation of either the MEK/1/2/ERK1/2 or PI3K/AKT1 pathway only partially mediates FGF2stimulated cell proliferation, but is sufficient to mediate the VEGFA-stimulated complete cell proliferation as well as FGF2- and VEGFA-stimulated complete cell migration in OFPAE cells (Zheng et al. 2008). Moreover, though activation of the p38 MAPK pathway critically mediated FGF2-stimulated cell proliferation and migration, it was not sufficient for mediating VEGFA-induced cell proliferation and migration in OFPAE cells (Zheng et al. 2006, Liao et al. 2010). These data imply that unlike the antagonistic roles of p38 MAPK in HLDME, BAE, and HUVE cells (Gratton et al. 2001, Issbrucker et al. 2003), p38 MAPK plays a positive role in regulating FGF2-, but not VEGFA-stimulated angiogenic activities of OFPAE cells. It is noteworthy that distinct signaling pathways might differentially mediate endothelial cell responses to FGF2 and VEGFA in different origins of placental endothelial cells. For example, we have reported that the PI3K/AKT1 pathway, but not the MEK/ERK1/2 pathway, mediates FGF2-stimulated cell proliferation, whereas the MEK1/2/ERK1/2 pathway, but not the

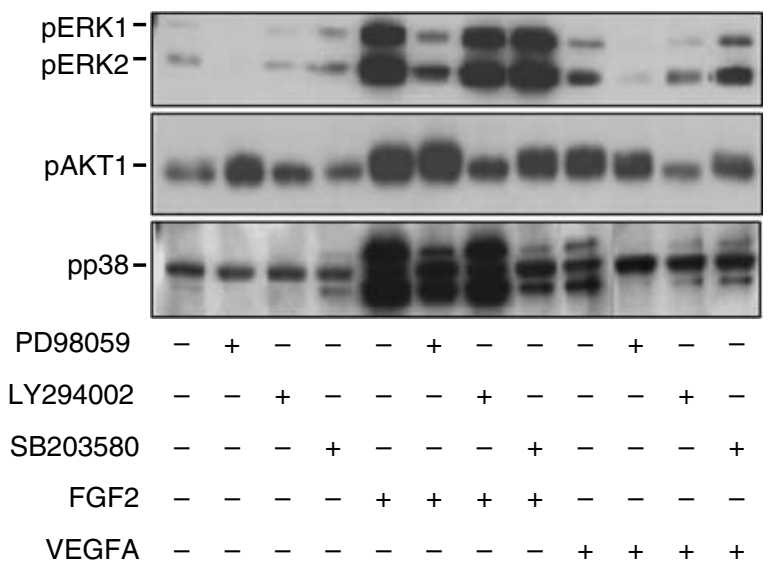

Figure 3 Effects of PD98059, LY294002, and SB203580 on phosphorylation of ERK1/2, AKT1, and p38 MAPK induced by FGF2 and VEGFA in OFPAE cells. After $16 \mathrm{~h}$ of serum starvation, cells were treated with $10 \mathrm{ng} / \mathrm{ml}$ of FGF2 or VEGFA for $10 \mathrm{~min}$ in the absence or presence of PD $98059(20 \mu \mathrm{M})$, LY294002 $(5 \mu \mathrm{M})$, or SB203580 (10 $\mu \mathrm{M} ; 1 \mathrm{~h}$ of pretreatment). Proteins (20 $\mu \mathrm{g} /$ lane) were subjected to western blotting using antibody against phosphospecific ERK1/2 (pERK1/2; 1:2000), AKT1 (pAKT1; 1:1000), or p38 MAPK (pp38; 1:1000).
PI3K/AKT1 pathway, mediates VEGFA-stimulated cell proliferation in human placental artery endothelial (HPAE) cells (Wang et al. 2009). Thus, a complex signaling network may mediate placental angiogenesis via a parallel, synergistic, and/or antagonistic manner (Yashima et al. 2001), possibly depending on signaling pathways and other vascular beds.

\section{Protein phosphatases: PPP2 and PPP3}

After activation, PKs must undergo inactivation, returning to a status ready for the next stimulus. One such mechanism to inactivate PKs is to dephosphorylate these kinases by protein phosphatases. Reflecting the huge diversity and breadth of functions regulated by protein dephosphorylation, higher eukaryotes encode $\sim 1000$ protein phosphatase genes that can be classified into at least three families (Barford et al. 1998). Within each family, the catalytic domains are highly conserved, with functional diversity endowed by regulatory subunits. These protein phosphatases can also be cataloged into two major classes: tyrosine phosphatases and serine/ threonine phosphatases, depending on their substrates (Liu et al. 2007). Serine/threonine phosphoprotein phosphatases (PPP), which specifically dephosphorylate phosphoserine and phosphothreonine residues, include PPP1, PPP2 (formally termed as PP2A), PPP3 (PP2B or calcineurin), and PPM1B (PP2C; Aramburu et al. 2004, Wilkins \& Molkentin 2004).

PPP2, one of the most extensively studied members of PPP, is believed to make up most of total serine/threonine phosphatase activity in cells (Lechward et al. 2001, Sontag 2001). PPP2 consists of catalytic (C) and scaffolding (A) subunits, which can bind to at least another 18 regulatory (B) subunits to form a trimeric holoenzyme (see Lechward et al. (2001), Sontag (2001), Cho \& Xu (2007), and Shi (2009) for details on PPP2 structures). In mammals, the subunit $\mathrm{C}$ of PPP2 has two major isoforms, $\alpha$ (PPP2CA) and $\beta$ (PPP2CB), between which PPP2CA is the most abundant isoform with the mRNA level approximately tenfold more than PPP2CB in most tissues (Lechward et al. 2001, Sontag 2001). It is still unclear if these two catalytic subunits have distinct functions. However, PPP2CB cannot completely compensate for the absence of PPP2CA in early embryonic development, as knockdown of PPP2CA alone in the mouse leads to early embryonic death, mostly owing to impaired mesoderm formation (Gotz et al. 1998). PPP2 mediates a variety of essential cellular processes such as cell growth, protein synthesis, and metabolism (Lechward et al. 2001, Sontag 2001), which could be partially a result of dephosphorylating and inactivating PKs such as ERK1/2, AKT1, and p38 MAPK (Alessi et al. 1995, Camps et al. 2000, Janssens \& Goris 2001, Silverstein et al. 2002, Lee et al. 2003, Liao \& Hung 2004, Van Kanegan et al. 2005).

Similar to PPP2, PPP3 is also composed of catalytic and regulatory subunits, including three catalytic $(\alpha, \beta$, and $\lambda)$ and two regulatory (B1 and B2; Perrino et al. 2002, Aramburu et al. 2004, Wilkins \& Molkentin 2004), among which $\alpha, \beta$, and $\mathrm{B} 1$ are widely expressed in mammalian tissues, whereas 
$\lambda$ and $\mathrm{B} 2$ are primarily found in the testis and brain. The PPP3 $\alpha$ (PPP3CA) appears to account for the majority (70-80\%) of total phosphatase activity of PPP3, while the $\beta$ (PPP3CB) constitutes 20-30\% (Im \& Rao 2004). Like PPP2, PPP3 also participates in many cellular functions (e.g. immune responses and cardiac hypertrophy), partially via directly dephosphorylating members of nuclear factor of activated $\mathrm{T}$ cell (NFAT) transcriptional factors, which in turn could be modulated by ERK1/2 (Aramburu et al. 2004, Wilkins \& Molkentin 2004). A role of PPP3 in mediating vascular development has been proposed as disruption of Ppp3r1, Nfatc3, and Nfatc4 genes in the mouse is embryonic lethal, due to impaired vascular development (Graef et al. 2001). This premise is further supported by the reports that suppression of PPP3 activity by its pharmacological inhibitor cyclosporin A (CsA) attenuated VEGFA-induced angiogenesis in HUVE cells (Hernandez et al. 2001) and intestinal microvascular endothelial cells (Rafiee et al. 2004). This inhibition by CsA was partially mediated by suppressing ERK1/2 and p38 MAPK activation (Rafiee et al. 2004, Farivar et al. 2005). Similar reciprocal relationships between PPP3 and ERK1/2 also have been reported in cardiomyocytes (Molkentin 2004) and in B cells (Gary-Gouy et al. 2006). However, in other types of cells, suppression of PPP3 activity could lead to completely opposite effects. For example, CsA has been shown to enhance ERK1/2 activation in human trophoblast cells (Du et al. 2007) and canine kidney epithelial cells (Kiely et al. 2003). Little is known about the mediation of PPP3 in activation of the PI3K/AKT1 cascade although it has been shown that PPP3 inhibition does not alter activation of the PI3K/AKT1 cascade in A549 cells (Wen et al. 2003).

The involvement of protein phosphatases in regulating endothelial functions has received much less attention compared with the PKs, particularly regarding the roles of PPP2/PPP3 in placental angiogenesis. Recently, we have identified the expression of PPP2CA and PPP3CA in OFPAE cells (Wang et al. 2008, Song et al. 2009). Nonetheless, suppression of PPP2CA protein expression by its specific siRNA did not significantly affect VEGFA- and FGF2stimulated OFPAE cell proliferation (Song et al. 2009). On the other hand, knockdown of PPP3CA protein by its specific siRNA only moderately enhanced VEGFA-stimulated cell proliferation ( $\sim 20 \%$ increase), but not FGF2-stimulated cell proliferation. Thus, PPP3CA alone has a critical role in modulating VEGFA-stimulated cell proliferation, whereas PPP2CA alone does not have such a role in modulating both VEGFA- and FGF2-stimulated cell proliferation in OFPAE cells.

Failure of PPP2CA suppression to alter VEGFA- and FGF2-stimulated OFPAE cell proliferation is in disagreement with the previous reports showing that inhibition of PPP2 activity promoted cell motility in BAE cells and primary human mouth endothelial cells (Gabel et al. 1999, Young et al. 2002) and cell proliferation in BAE cells (Murata et al. 1996). In addition, although participation of PPP3 in VEGFA- but not FGF2-stimulated OFPAE cell proliferation was consistent with the previous reports using other endothelial cell types (Hernandez et al. 2001, Rafiee et al. 2004), the PPP3CA knockdown-enhanced VEGFA-stimulated OFPAE cell proliferation also contrasted with these previous reports (Hernandez et al. 2001, Rafiee et al. 2004). It is currently unknown whether different origins of endothelial cells cause these different or complete opposite actions of PPP3CA in modulating cell proliferation. Nonetheless, in those previous studies (Murata et al. 1996, Gabel et al. 1999, Hernandez et al. 2001, Young et al. 2002, Rafiee et al. 2004), inhibition of PPP2 and PPP3 activity was carried out by their pharmacological inhibitors (okadaic acid or cantharidin for PPP2 or CsA for PPP3). Given that the specificity of these pharmacological inhibitors is highly dependent on the doses, and relatively high doses of pharmacological PPP2 inhibitors were used in these studies, the effects of PPP2 and PPP3 inhibition on endothelial responses by their pharmacological inhibitors might result from suppression of multiple protein phosphatases. Moreover unlike these pharmacological inhibitors, which attenuate/block all catalytic subunits of PPP2 and PPP3, the siRNA used in OFPAE cells targeted only on $\alpha$ of PPP 2 and PPP3. This specific knockdown of a single catalytic subunit by the siRNA might cause upregulation of PPP2CB and PPP3CB to compensate the loss of phosphatase activity after PPP2CA and PPP3CA suppression, leading to differential modulation of different cell responses. Conversely, the different duration of PPP2 and PPP3 inhibition before growth factor stimulation can also contribute to such different cell responses caused by these pharmacological inhibitors $(30 \mathrm{~min}-1 \mathrm{~h})$ and siRNA (at least $16 \mathrm{~h}$ ). This supposition is supported by a recent observation that chronic and acute inhibition of PPP2 induced the opposite regulation of ERK1/2 and AKT1 activation since the PPP2 siRNA induced chronic ERK1/2 and AKT1 hyperphosphorylation, downregulating signaling molecules upstream of Ras in response to growth factors including FGF2 (Van Kanegan et al. 2005). In OFPAE cells, suppression of PPP2CA and PPP3CA by their special siRNA did attenuate FGF2-induced ERK1/2 and AKT1 activation (Wang et al. 2008, Song et al. 2009). Thus, a negative feedback mechanism might be involved in PPP2CA and PPP3CA modulation of ERK1/2 and AKT1 activation induced by FGF2 in OFPAE cells.

The roles of protein phosphatases in the modulation of placental angiogenesis and underlying signaling are much more complicated than originally thought, as PPP2 and PPP3 differentially modulated the VEGFA- and FGF2-stimulated cell proliferation and signaling cascades in OFPAE cells (Wang et al. 2008, Song et al. 2009, Fig. 4). Moreover, protein phosphatases other than PPP2 and PPP3 such as MAPK phosphatase, and phosphatase and tensin homolog could play a more important role in differential modulation of ERK1/2, AKT1, and p38 MAPK activation in placental endothelial cells, ultimately regulating placental angiogenesis. 


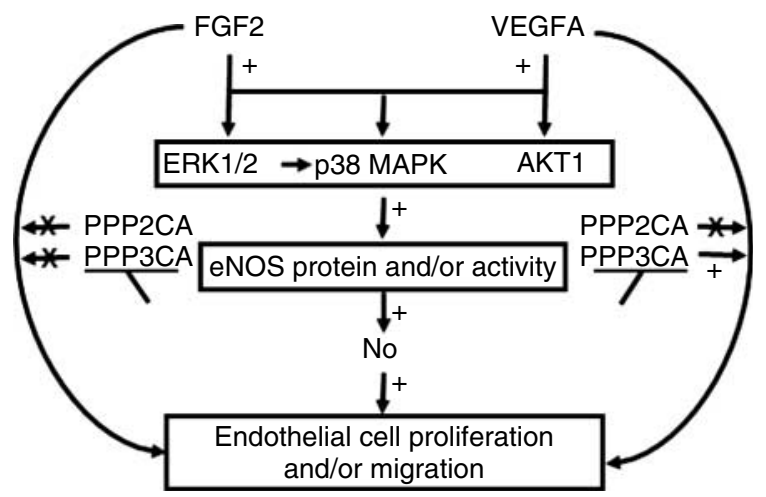

Figure $4 \mathrm{~A}$ proposed model of the signal transduction pathways for FGF2- and VEGFA-stimulated proliferation and migration in OFPAE cells. In this working model, we propose that FGF2 and VEGFA activate ERK1/2, AKT1, and p38 MAPK, which in turn increase eNOS protein expression and/or eNOS activity, increasing $\mathrm{NO}$ production. This increased $\mathrm{NO}$ as an intracellular signaling modulates FGF2- and VEGFA-stimulated cell proliferation and migration. Inhibition of PPP3CA, but not PPP2CA, enhances VEGFA-, but not FGF2-stimulated cell proliferation while failing to affect FGF2- and VEGFA-induced activation of ERK1/2 and AKT1, suggesting that as-yet unidentified signaling molecules play an important role in FGF2- and VEGFA-stimulated cell proliferation after knockdown of PPP3CA in OFPAE cells.

\section{Angiogenesis and NO}

Over the past two decades, it has become clear that apart from being a potent vasodilator (Dulak \& Jozkowicz 2003), NO is also a key mediator of angiogenesis (Pipili-Synetos et al. 1993, Ziche et al. 1993, 1994, 1997a,b, Noiri et al. 1997, Babaei et al. 1998, Murohara et al. 1998, Parenti et al. 1998, Bussolati et al. 2001, Hida et al. 2004). The participation of NO in mediating angiogenesis was first reported by Pipili-Synetos et al. (1993) using the chick embryo chorioallantoic membrane model, in which NO was believed to act as an anti-angiogenic mediator. However, Ziche et al. have subsequently provided several lines of evidence showing that NO functions as a positive mediator of angiogenesis (Ziche et al. 1993, 1994, 1997a,b, Parenti et al. 1998). They reported that both exogenous and endogenous NO stimulated cellular DNA synthesis, proliferation, and migration in bovine postcapillary venule endothelial cells in vitro (Ziche et al. 1993, 1994) and that exogenous $\mathrm{NO}$ potentiated angiogenesis in the rabbit 'cornea pocket assay', in which VEGFA-induced angiogenesis was also completely inhibited by the NOS inhibitor, L-NAME (Ziche et al. 1997a). Using the same in vivo assay, they further proposed that VEGFA-, but not FGF2-induced angiogenesis was mediated by NOS via the $\mathrm{NO} /$ cyclic guanylate monophosphate pathway (Ziche et al. 1997a). Positive involvement of endogenous $\mathrm{NO}$ as a downstream signal of VEGFA-induced angiogenesis was confirmed by in vivo observations showing significantly improved angiogenesis in response to dietary supplementation L-arginine in the rabbit (Murohara et al. 1998) and in the rat (eNOS overexpression, Namba et al. 2003) ischemia models, as well as the considerably limited angiogenesis in eNOS knockout mice (Fukumura et al. 2001). Bussolati et al. (2001) have also proposed that VEGFR1 promoted formation of capillary networks in HUVE cells via NO, while inhibiting VEGFR2-mediated cell proliferation. Exogenous NO can also act as a crucial signal in the angiogenic response, in which NO promotes FGF2-induced endothelial cell differentiation into capillary tubes, while terminating the proliferative actions in both HUVE and calf pulmonary artery endothelial cells (Babaei et al. 1998). Thus, NO differentially regulates FGF2- and VEGFA-induced angiogenesis at different steps (i.e. proliferation/migration vs capillary tube formation).

Expression of eNOS and iNOS has been identified in the placenta of human, rhesus monkey, rat, and sheep (Conrad et al. 1993, Myatt et al. 1993, Zarlingo et al. 1997). In association with robust fetoplacental angiogenesis (Reynolds \& Redmer 1995, Magness \& Zheng 1996), the NO level was increased in maternal circulation as pregnancy progresses in sheep (Vonnahme et al. 2005), and in late human pregnancy (Williams et al. 1997). In ovine cotyledons (fetal side of the placentome) during late pregnancy, eNOS, but not iNOS, was present in the fetal component of the placentome, primarily in microvascular endothelial cells in the villous core (Zheng et al. 2000), similar to the findings reported in the term placentae of rhesus monkeys, baboon, guinea-pig, rat, and sheep (Zarlingo et al. 1997). Together, with the observation that increased expression of eNOS but not iNOS protein runs parallel to increased total $\mathrm{NO}$ (nitrate and nitrite) production (Zheng et al. 2000), eNOS seems to be a predominant isoform of NOS responsible for the NO production in the fetal component of the placentome during late ovine pregnancy. In addition, these increases in eNOS protein expression and NO production in the fetal component of the placentome are temporally associated with increased placental vascular density and expression of FGF2 (Magness \& Zheng 1996, Zheng et al. 1997), supporting a critical role of $\mathrm{NO}$ in modulating fetoplacental angiogenesis.

Indeed, similar to the $\mathrm{NO}$-mediated angiogenic responses in those endothelial cells reported (Ziche et al. 1993, 1994, 1997a,b, Parenti et al. 1998), exogenous NO (sodium nitroprusside (SNP), a potent NO donor) alone promoted OFPAE and HPAE cell proliferation (Zheng et al. 2006) and OFPAE migration (Liao et al. 2010). Of note, NO mediation of angiogenesis is highly dependent on NO levels. At relatively lower levels, NO might be pro-angiogenic as shown in OFPAE cells (Zheng et al. 2006, Liao et al. 2010) and in other endothelial cells (Fukuo et al. 1995, Hida et al. 2004), while at relatively high levels NO could act as a pro-apoptotic or anti-angiogenic factor (Kimura \& Esumi 2003, Zheng et al. 2006). These seemingly contradictory observations are likely due to the reaction of NO with super-oxidants, which in turn forms peroxynitrite, causing 
cytostasis and apoptosis (Pacher et al. 2007, Frey et al. 2009). Interestingly, the stimulatory actions of exogenous $\mathrm{NO}$ on OFPAE cell proliferation and migration (Zheng et al. 2006, Liao et al. 2010) were not associated with increased mRNA expression of FGF2, VEGFA, or their major receptors (VEGFR1, VEGFR2, NP1, NP2, and FGFR1; Zheng et al. 2006). This is contradictory to previous reports demonstrating existence of the VEGFA/FGF2-NO reciprocal regulation between endothelial cells and the surrounding non-endothelial cells, including vascular smooth muscle cells, macrophages, keratinocytes, and tumor cells as described previously (Tuder et al. 1995, Dembinska-Kiec et al. 1997, Tsurumi et al. 1997, Ziche et al. 1997b, Frank et al. 1999, Dulak \& Jozkowicz 2003, Namba et al. 2003, Zhang et al. 2003). In these studies, NO promoted angiogenesis via increasing VEGFA expression in the rat ischemic hindlimb (Namba et al. 2003) and brain (Zhang et al. 2003) or FGF2 expression in bovine coronary venular endothelium (Ziche et al. 1997b) or suppressing mRNA expression of VEGFA and/ or its receptors (VEGFR1 and VEGFR2) in rat vascular smooth muscle (Tsurumi et al. 1997), in rat lung tissue (Tuder et al. 1995), and in rat renal mesangial cells (Frank et al. 1999). Thus, the observation that SNP-derived NO failed to alter expression of FGF2, VEGFA, and their major receptors in OFPAE cells cultured under standard cell culture conditions $\left(37^{\circ} \mathrm{C}, 5 \% \mathrm{CO}_{2}, 95 \%\right.$ air; Zheng et al. 2006) implicates that the VEGF/FGF2-NO reciprocal regulation may not occur within placental endothelia, although such regulation may exist between placental vascular endothelia and smooth muscle cells. It is noteworthy that this discrepancy in such $\mathrm{NO}$ regulation could also be attributed to different $\mathrm{NO}$ donors used since they are known to differentially mediate the cellular responses, possibly due to differences in the amount and duration of NO generation (Dulak \& Jozkowicz 2003). Moreover, in our studies, even after stimulated with VEGFA and FGF2 at physiological concentrations, OFPAE and HUVE cells under standard culture conditions produced much lower levels of NO (unpublished data) compared with those released from SNP at doses $(1-10 \mu \mathrm{M})$ that stimulated OFPAE cell proliferation (Zheng et al. 2006). This suggests that under physiological conditions, NO generated by these endothelial cells might never reach dangerous levels, even when one assumes the existence of a positive feedback loop for VEGFA/FGF2 and NO between placental vascular endothelial and smooth muscle cells. This phenomenon could also be attributed to the fact that NO itself can negatively regulate eNOS dimerization, expression and/or activity in endothelial cells, possibly via $S$-nitrosylation, thereby decreasing NO production (Sheehy et al. 1998, Black et al. 1999, Ravi et al. 2004, Kopincova et al. 2011) and potentially preventing apoptosis.

What the downstream signaling is for exogenous $\mathrm{NO}$-mediated angiogenesis is still poorly defined. We have found that an $\mathrm{NO}$ donor might activate different signaling pathways, depending on the origin of the cells utilized. For example, SNP induced activation of ERK1/2, but not AKT1 in OFPAE cells, whereas it activated both kinases in HPAE cells (Zheng et al. 2006). In addition, a previous report has also shown that NO donors ( $S$-nitosol-L-glutathione and $S$-nitroso- $N$-penicillamine) promote migration and angiogenesis of human and bovine endothelial cells via activation of the soluble guanylate cyclase (sGC)/cGMP/PI3K/AKT1 pathway (Kawasaki et al. 2003). However, OFPAE cells used (Zheng et al. 2006, Liao et al. 2010) did not have any detectable sGC activity and did not produce cGMP in response to SNP (Itoh et al. 1999). Thus, exogenous $\mathrm{NO}$-stimulated angiogenic responses and $\mathrm{NO}$-induced ERK1/2 activation (Zheng et al. 2006, Liao et al. 2010) are unlikely coupled to the sGC/cGMP pathway in OFPAE cells.

It is well recognized that FGF2 and VEGFA promote NO production by endothelial cells isolated from either placental (Zheng et al. 2008, Liao et al. 2010) or other non-placental tissues (Cuevas et al. 1991, Kadota et al. 1995, Kostyk et al. 1995, Rousseau et al. 1997, 2000, Babaei et al. 1998, Murohara et al. 1998, Dimmeler et al. 1999, Fulton et al. 1999, 2001, Michell et al. 1999, Morales-Ruiz et al. 2000, Fukumura et al. 2001, Zubilewicz et al. 2001, Namba et al. 2003). In OFPAE cells, FGF2- and VEGFA-stimulated NO production by increasing eNOS protein expression (FGF2) or directly enhancing enzymatic activity of eNOS (FGF2/ VEGFA; Mata-Greenwood et al. 2008, 2010, Zheng et al. 2008, Liao et al. 2010), in which FGF2 increased eNOS expression and NO production was mediated primarily by AP-1-dependent transcription involving JunB and Fra1 upregulation (Mata-Greenwood et al. 2010). After generation, endogenous NO positively mediated both FGF2- and VEGFA-stimulated cell proliferation and VEGFA-stimulated migration in OFPAE cells, primarily via an intracellular mechanism (Zheng et al. 2008, Liao et al. 2010). However, in contrast to the previous studies showing that $\mathrm{NO}$ acted as an upstream signaling of ERK1/2 in VEGFA-stimulated cell proliferation and migration in non-placental endothelial cells (Ziche et al. 1997a,b, Parenti et al. 1998), we found that NO lay downstream of ERK1/2 and AKT1 in OFPAE cells (Li et al. 2004, Zheng et al. 2008), consistent with the observations made in other types of endothelial cells (Dimmeler et al. 1999, Fulton et al. 1999, Souttou et al. 2001).

Activation of eNOS can be tightly regulated by multiple processes including phosphorylation and nitrosylation (Fulton et al. 2001, Boo \& Jo 2003, Kopincova et al. 2011), the former having been recognized as critical for eNOS activation (Fulton et al. 2001, Boo \& Jo 2003). Human eNOS can be phosphorylated on at least three residues: serine 116 (Ser116) and 1177 (Ser1177; Ser1179 in ovine and bovine) and threonine 495 (Thr495; Thr497 in ovine and bovine). Upon phosphorylation of these residues by the kinases, eNOS activity could be either enhanced (at Ser1177) or attenuated (at Thr495 and Ser116; Boo \& Jo 2003). To date, one of the best-studied signaling pathways that mediate eNOS phosphorylation is PI3K/AKT1. It has been reported that VEGFA-activated PI3K/AKT1 directly phosphorylates eNOS Ser1179, leading to stimulating NO production, and 
endothelial migration, proliferation, and capillary-like structure formation (Dimmeler et al. 1999, Fulton et al. 1999, Michell et al. 1999 Morales-Ruiz et al. 2000, Souttou et al. 2001). In OFPAE cells, shear stress-elevated NO production was associated with an increased NOS Ser1179 phosphorylation, which was blocked by PI3K inhibitors Wortmannin and LY294002, but not the MEK inhibitor UO126, suggesting that PI3K/Akt-eNOS Ser1179 is also a major signaling pathway for activating eNOS activity in OFPAE cells (Li et al. 2003, 2004). In contrast to Ser1177, the VEGFA-induced eNOS Ser116 phosphorylation was completely blocked by the PKC inhibitor calphostin, but not by either Wortmannin or U0126 (Kou et al. 2002). Thus, these data indicate that eNOS phosphorylation at different sites is controlled by a variety of PKs, coordinating eNOS activity and NO production.

Little is known about signaling pathways modulating eNOS dephosphorylation by protein phosphatases. It has been shown that PPP2 preferentially dephosphorylates eNOS at Thr497 and Ser1177, but not at Ser116, leading to deactivation of eNOS and impaired angiogenesis (Michell et al. 2001, Greif et al. 2002, Urbich et al. 2002, Leidi et al. 2010). Intriguingly, NO was also able to activate PPP2 to modulate chromatin folding in HUVE cells (Illi et al. 2008). Thus, the reciprocal interactions between protein phosphatases and NO might play a critical role in mediating placental angiogenesis.

\section{Conclusions and perspectives}

In conclusion, an increasing body of evidence either from our laboratories or other investigators has shown that FGF2 and VEGFA regulate fetoplacental angiogenesis via an extremely complex signaling network involving multiple of PKs and phosphatases as well as NO (Fig. 4). While much progress has been made, many difficult challenges still remain for dissecting signaling mechanisms underlying fetoplacental angiogenesis. For example, how can we isolate, establish, and maintain fetoplacental microvascular endothelial cell models with highly homogenous cellular purity? What and how are protein phosphatases activated, and how do they modulate activation of PKs in fetoplacental angiogenesis? Moreover, to date, almost all endothelial cell models used to study placental angiogenesis have been cultured and expanded under an ambient $\mathrm{O}_{2}$ level $\left(\sim 21 \%\right.$ or $\left.\mathrm{pO}_{2} \sim 160 \mathrm{mmHg}\right)$, which obviously does not closely reflect in vivo physiological $\mathrm{O}_{2}$ levels under which placental endothelial cells constantly reside $\left(\sim 1 \cdot 5-8 \cdot 0 \% \mathrm{O}_{2}\right.$ or $\mathrm{pO}_{2} 12-60 \mathrm{mmHg}$; Meschia 2004, Bertout et al. 2008). These endothelial cells cultured under such conditions might represent a subpopulation of endothelial cells that have adapted to hyperoxia. Therefore, culturing and investigating placental endothelial cells under chronic physiological $\mathrm{O}_{2}$ levels are critical to provide information on fetoplacental angiogenesis and underlying signaling mechanisms, more closely mimicking in vivo states.

\section{Declaration of interest}

The authors declare that there is no conflict of interest that could be perceived as prejudicing the impartiality of the review reported.

\section{Funding}

This work was supported by the US National Institutes of Health grants HL64703 (JZ) and HD38843 (Ronald R Magness / JZ).

\section{Acknowledgements}

We thank our collaborators and colleagues (Drs Dong-bao Chen, Wu-Xiang Liao, Eugenia Mata-Greenwood, Ian M Bird, and Ronald R Magness), current and former graduate students (Drs Song Yang, Cai-feng Dai, Yi-Zhou Jiang, and Mr Yan Li), and laboratory personnel (Ms Wen YX, Mr Austin JL, and $\mathrm{Mr}$ Phernetton TM) for their valuable contributions to this work. We thank Dr Ronald R Magness for his critical reading of the manuscript. We also wish to acknowledge the financial support from the U.S. National Institutes of Health (HL64703 to J Z and HD38843 to Ronald R Magness/J Z).

\section{References}

Aitsebaomo J, Portbury AL, Schisler JC \& Patterson C 2008 Brothers and sisters: molecular insights into arterial-venous heterogeneity. Circulation Research 103 929-939. (doi:10.1161/CIRCRESAHA.108.184937)

Alessi DR, Gomez N, Moorhead G, Lewis T, Keyse SM \& Cohen P 1995 Inactivation of $\mathrm{p} 42 \mathrm{MAP}$ kinase by protein phosphatase $2 \mathrm{~A}$ and a protein tyrosine phosphatase, but not CL100, in various cell lines. Current Biology $\mathbf{5}$ 283-295. (doi:10.1016/S0960-9822(95)00059-5)

Alexander G 1974 Birth weight of lambs. Influences and consequences. In Ciba Foundation Symposium 27: Size at Birth, pp 215-239. Eds K Elliott \& J Knight. New York: Elsevier Publisher.

Aramburu J, Heitman J \& Crabtree GR 2004 Calcineurin: a central controller of signaling in eukaryotes. EMBO Reports 5 343-348. (doi:10.1038/sj. embor.7400133)

Arnal JF, Tack I, Besombes JP, Pipy B \& Negre-Salvayre A 1996 Nitric oxide and superoxide anion production during endothelial cell proliferation. American Journal of Physiology 271 C1521-C1526.

Babaei S, Teichert-Kuliszewska K, Monge JC, Mohamed F, Bendeck MP \& Stewart DJ 1998 Role of nitric oxide in the angiogenic response in vitro to basic fibroblast growth factor. Circulation Research 82 1007-1015.

Barcroft J \& Barron DH 1946 Observations upon the form and relations of the maternal and fetal vessels in the placenta of the sheep. Anatomical Record 94 569-595. (doi:10.1002/ar.1090940403)

Barford D, Das AK \& Egloff MP 1998 The structure and mechanism of protein phosphatases: insights into catalysis and regulation. Annual Review of Biophysics and Biomolecular Structure 27 133-164. (doi:10.1146/annurev. biophys.27.1.133)

Baudin B, Bruneel A, Bosselut N \& Vaubourdolle M 2007 A protocol for isolation and culture of human umbilical vein endothelial cells. Nature Protocols 2 481-485. (doi:10.1038/nprot.2007.54)

Benirschke K, Kaufmann P \& Baergen R 2006a Architecture of normal villous trees. In Pathology of the Human Placenta, 5th edn, pp 121-173. Eds Benirschke K, Kaufmann P \& Baergen R. New York: Springer Science + Business Media.

Benirschke K, Kaufmann P \& Baergen R 2006b Anatomy and pathology of the umbilical cord. In Pathology of the Human Placenta, 5th edn, pp 380-451. Eds Benirschke K, Kaufmann P \& Baergen R. New York: Springer Science + Business Media.

Bertout JA, Patel SA \& Simon MC 2008 The impact of $\mathrm{O}_{2}$ availability on human cancer. Nature Reviews. Cancer 8 967-975. (doi:10.1038/nrc2540) 
Black SM, Heidersbach RS, McMullan DM, Bekker JM, Johengen MJ \& Fineman JR 1999 Inhaled nitric oxide inhibits NOS activity in lambs: potential mechanism for rebound pulmonary hypertension. American Journal of Physiology 277 H1849-H1856.

Blumer KJ \& Johnson GL 1994 Diversity in function and regulation of MAP kinase pathways. Trends in Biochemical Sciences 19 236-240. (doi:10.1016/ 0968-0004(94)90147-3)

Boilly B, Vercoutter-Edouart AS, Hondermarck H, Nurcombe V \& Le Bourhis X 2000 FGF signals for cell proliferation and migration through different pathways. Cytokine \& Growth Factor Reviews 11 295-302. (doi:10. 1016/S1359-6101(00)00014-9)

Boo YC \& Jo H 2003 Flow-dependent regulation of endothelial nitric oxide synthase: role of protein kinases. American Journal of Physiology 285 C499-C508. (doi:10.1152/ajpcell.00122.2003)

Brownbill P, McKeeman GC, Brockelsby JC, Crocker IP \& Sibley CP 2007 Vasoactive and permeability effects of vascular endothelial growth factor165 in the term in vitro dually perfused human placental lobule. Endocrinology 148 4734-4744. (doi:10.1210/en.2007-0180)

Bussolati B, Dunk C, Grohman M, Kontos CD, Mason J \& Ahmed A 2001 Vascular endothelial growth factor receptor-1 modulates vascular endothelial growth factor-mediated angiogenesis via nitric oxide. American Journal of Pathology 159 993-1008. (doi:10.1016/S0002-9440(10)61775-0)

Camps M, Nichols A \& Arkinstall S 2000 Dual specificity phosphatases: a gene family for control of MAP kinase function. FASEB Journal 14 6-16.

Challier JC, Kacemi A \& Olive G 1995 Mixed culture of pericytes and endothelial cells from fetal microvessels of the human placenta. Cellular and Molecular Biology 41 233-241.

Chi JT, Chang HY, Haraldsen G, Jahnsen FL, Troyanskaya OG, Chang DS, Wang Z, Rockson SG, van de Rijn M, Botstein D et al. 2003 Endothelial cell diversity revealed by global expression profiling. PNAS $\mathbf{1 0 0}$ 10623-10628. (doi:10.1073/pnas.1434429100)

Cho US \& Xu W 2007 Crystal structure of a protein phosphatase 2A heterotrimeric holoenzyme. Nature 445 53-57. (doi:10.1038/nature05351)

Cobb MH 1999 MAP kinase pathways. Progress in Biophysics and Molecular Biology 71 479-500. (doi:10.1016/S0079-6107(98)00056-X)

Conrad KP, Joffe GM, Kruszyna H, Kruszyna R, Rochelle LG, Smith RP, Chavez JE \& Mosher MD 1993 Identification of increased nitric oxide biosynthesis during pregnancy in rats. FASEB Journal $7566-571$.

Cross MJ, Dixelius J, Matsumoto T \& Claesson-Welsh L 2003 VEGF-receptor signal transduction. Trends in Biochemical Sciences 28 488-494. (doi:10.1016/ S0968-0004(03)00193-2)

Cuevas P, Carceller F, Ortega S, Zazo M, Nieto I \& Gimenez-Gallego G 1991 Hypotensive activity of fibroblast growth factor. Science 254 1808-1810. (doi:10.1126/science.1957172)

D'Angelo G, Struman I, Martial J \& Weiner RI 1995 Activation of mitogenactivated protein kinases by vascular endothelial growth factor and basic fibroblast growth factor in capillary endothelial cells is inhibited by the antiangiogenic factor $16-\mathrm{kDa}$ N-terminal fragment of prolactin. PNAS 92 6374-6378. (doi:10.1073/pnas.92.14.6374)

Davis RJ 1993 The mitogen-activated protein kinase signal transduction pathway. Journal of Biological Chemistry 268 14553-14556.

Dembinska-Kiec A, Dulak J, Partyka L, Huk I \& Mailnski T 1997 VEGFnitric oxide reciprocal regulation. Nature Medicine 3 1177. (doi:10.1038/ nm1197-1177a)

Dimmeler S, Fleming I, Fisslthaler B, Hermann C, Busse R \& Zeiher AM 1999 Activation of nitric oxide synthase in endothelial cells by Aktdependent phosphorylation. Nature 399 601-605. (doi:10.1038/21224)

Du MR, Zhou WH, Yan FT, Zhu XY, He YY, Yang JY \& Li DJ 2007 Cyclosporin A induces titin expression via MAPK/ERK signaling and improves proliferative and invasive potential of human trophoblast cells. Human Reproduction 22 2528-2537. (doi:10.1093/humrep/dem222)

Dulak J \& Jozkowicz A 2003 Regulation of vascular endothelial growth factor synthesis by nitric oxide: facts and controversies. Antioxidants $\&$ Redox Signaling 5 123-132. (doi:10.1089/152308603321223612)

Dye JF, Vause S, Johnston T, Clark P, Firth JA, D'Souza SW, Sibley CP \& Glazier JD 2004 Characterization of cationic amino acid transporters and expression of endothelial nitric oxide synthase in human placental microvascular endothelial cells. FASEB Journal 18 125-127. (doi:10.1096/ fj.02-0916fje)

Farivar AS, Mackinnon-Patterson BC, Barnes AD, McCourtie AS \& Mulligan MS 2005 Cyclosporine modulates the response to hypoxiareoxygenation in pulmonary artery endothelial cells. Annals of Thoracic Surgery 79 1010-1016. (doi:10.1016/j.athoracsur.2004.08.078)

Ferrara N, Gerber HP \& LeCouter J 2003 The biology of VEGF and its receptors. Nature Medicine 9 669-676. (doi:10.1038/nm0603-669)

Fong GH, Rossant J, Gertsenstein M \& Breitman ML 1995 Role of the Flt-1 receptor tyrosine kinase in regulating the assembly of vascular endothelium. Nature 376 66-70. (doi:10.1038/376066a))

Frank S, Stallmeyer B, Kampfer H, Schaffner C \& Pfeilschifter J 1999 Differential regulation of vascular endothelial growth factor and its receptor fms-like-tyrosine kinase is mediated by nitric oxide in rat renal mesangial cells. Biochemical Journal 338 367-374. (doi:10.1042/0264-6021:3380367)

Frey RS, Ushio-Fukai M \& Malik AB 2009 NADPH oxidase-dependent signaling in endothelial cells: role in physiology and pathophysiology. Antioxidants \& Redox Signaling 11 791-810. (doi:10.1089/ars.2008.2220)

Fukumura D, Gohongi T, Kadambi A, Izumi Y, Ang J, Yun CO, Buerk DG, Huang PL \& Jain RK 2001 Predominant role of endothelial nitric oxide synthase in vascular endothelial growth factor-induced angiogenesis and vascular permeability. PNAS 98 2604-2609. (doi:10.1073/pnas. 041359198)

Fukuo K, Inoue T, Morimoto S, Nakahashi T, Yasuda O, Kitano S, Sasada R \& Ogihara T 1995 Nitric oxide mediates cytotoxicity and basic fibroblast growth factor release in cultured vascular smooth muscle cells. A possible mechanism of neovascularization in atherosclerotic plaques. Journal of Clinical Investigation 95 669-676. (doi:10.1172/JCI117712)

Fulton D, Gratton JP, McCabe TJ, Fontana J, Fujio Y, Walsh K, Franke TF, Papapetropoulos A \& Sessa WC 1999 Regulation of endothelium-derived nitric oxide production by the protein kinase Akt. Nature 399 597-601. (doi:10.1038/21218)

Fulton D, Gratton JP \& Sessa WC 2001 Post-translational control of endothelial nitric oxide synthase: why isn't calcium/calmodulin enough? Journal of Pharmacology and Experimental Therapeutics 299 818-824.

Gabel S, Benefield J, Meisinger J, Petruzzelli GJ \& Young M 1999 Protein phosphatases 1 and 2A maintain endothelial cells in a resting state, limiting the motility that is needed for the morphogenic process of angiogenesis. Otolaryngology - Head and Neck Surgery 121 463-468. (doi:10.1016/S01945998(99)70238-X)

Gary-Gouy H, Sainz-Perez A, Bismuth G, Ghadiri A, Perrino BA \& Dalloul A 2006 Cyclosporin-A inhibits ERK phosphorylation in B cells by modulating the binding of $\mathrm{Raf}$ protein to $\mathrm{Bcl} 2$. Biochemical and Biophysical Research Communications 344 134-139. (doi:10.1016/j.bbrc.2006.03.121)

Gille H, Kowalski J, Yu L, Chen H, Pisabarro MT, Davis-Smyth T \& Ferrara N $2000 \mathrm{~A}$ repressor sequence in the juxtamembrane domain of Flt-1 (VEGFR-1) constitutively inhibits vascular endothelial growth factordependent phosphatidylinositol 3 '-kinase activation and endothelial cell migration. EMBO Journal 19 4064-4073. (doi:10.1093/emboj/19.15. 4064)

Gotz J, Probst A, Ehler E, Hemmings B \& Kues W 1998 Delayed embryonic lethality in mice lacking protein phosphatase $2 \mathrm{~A}$ catalytic subunit $\mathrm{C}$ alpha. PNAS 95 12370-12375. (doi:10.1073/pnas.95.21.12370)

Graef IA, Chen F, Chen L, Kuo A \& Crabtree GR 2001 Signals transduced by $\mathrm{Ca}(2+) /$ calcineurin and NFATc3/c4 pattern the developing vasculature. Cell 105 863-875. (doi:10.1016/S0092-8674(01)00396-8)

Gratton JP, Morales-Ruiz M, Kureishi Y, Fulton D, Walsh K \& Sessa WC 2001 Akt down-regulation of p38 signaling provides a novel mechanism of vascular endothelial growth factor-mediated cytoprotection in endothelial cells. Journal of Biological Chemistry 276 30359-30365. (doi:10.1074/jbc. M009698200)

Greif DM, Kou R \& Michel T 2002 Site-specific dephosphorylation of endothelial nitric oxide synthase by protein phosphatase $2 \mathrm{~A}$ : evidence for crosstalk between phosphorylation sites. Biochemistry 41 15845-15853. (doi:10.1021/bi026732g)

Hernandez GL, Volpert OV, Iniguez MA, Lorenzo E, Martinez-MartInez S, Grau S, Fresno M \& Redondo JM 2001 Selective inhibition of vascular 
endothelial growth factor-mediated angiogenesis by cyclosporin A: roles of the nuclear factor of activated $\mathrm{T}$ cells and cyclooxygenase 2. Journal of Experimental Medicine 193 607-620. (doi:10.1084/jem.193.5.607)

Hida A, Kawakami A, Miyashita T, Yamasaki S, Nakashima K, Tanaka F, Izumi Y, Tamai M, Huang M, Ida H et al. 2004 Nitric oxide acts on the mitochondria and protects human endothelial cells from apoptosis. Journal of Laboratory and Clinical Medicine 144 148-155. (doi:10.1016/j.lab. 2004.04.009)

Illi B, Dello Russo C, Colussi C, Rosati J, Pallaoro M, Spallotta F, Rotili D, Valente S, Ragone G, Martelli F et al. 2008 Nitric oxide modulates chromatin folding in human endothelial cells via protein phosphatase $2 \mathrm{~A}$ activation and class II histone deacetylases nuclear shuttling. Circulation Research 102 51-58. (doi:10.1161/CIRCRESAHA.107.157305)

Im SH \& Rao A 2004 Activation and deactivation of gene expression by calcium-calcineurin-NFAT-mediated signaling. Molecular Cell 18 1-9.

Issbrucker K, Marti HH, Hippenstiel S, Springmann G, Voswinckel R, Gaumann A, Breier G, Drexler HC, Suttorp N \& Clauss M 2003 p38 MAP kinase - a molecular switch between VEGF-induced angiogenesis and vascular hyperpermeability. FASEB Journal 17 262-264. (doi:10.1096/fj. 02-0329fje)

Itoh H, Zheng J, Bird IM, Nakao K \& Magness RR 1999 Basic fibroblast growth factor down-regulates the expression of clearance receptor of natriuretic peptides via mitogen-activated protein kinase cascade in ovine feto-placental artery endothelial cells. American Journal of Physiology 277 R541-R547.

Janssens V \& Goris J 2001 Protein phosphatase 2A: a highly regulated family of serine/threonine phosphatases implicated in cell growth and signalling. Biochemistry Journal 353 417-439. (doi:10.1042/0264-6021:3530417)

Kacemi A, Galtier M, Espie MJ \& Challier JC 1997 Isolation of villous microvessels from the human placenta. Comptes Rendus des Séances de l'Académie des Sciences. Série III, Sciences de la Vie 320 171-177.

Kadota O, Ohta S, Kumon Y, Sakaki S, Matsuda S \& Sakanaka M 1995 Role of basic fibroblast growth factor in the regulation of rat basilar artery tone in vivo. Neuroscience Letters 199 99-102. (doi:10.1016/03043940(95)12040-B)

Kawasaki K, Smith RS Jr, Hsieh CM, Sun J, Chao J \& Liao JK 2003 Activation of the phosphatidylinositol 3-kinase/protein kinase Akt pathway mediates nitric oxide-induced endothelial cell migration and angiogenesis. Molecular and Cellular Biology 23 5726-5737. (doi:10.1128/MCB.23.16. 5726-5737.2003)

Kiely B, Feldman G \& Ryan MP 2003 Modulation of renal epithelial barrier function by mitogen-activated protein kinases (MAPKs): mechanism of cyclosporin A-induced increase in transepithelial resistance. Kidney International 63 908-916. (doi:10.1046/j.1523-1755.2003.00804.x)

Kimura H \& Esumi H 2003 Reciprocal regulation between nitric oxide and vascular endothelial growth factor in angiogenesis. Acta Biochimica Polonica $5049-59$.

Klagsbrun M \& D'Amore PA 1991 Regulators of angiogenesis. Annual Review of Physiology 53 217-239. (doi:10.1146/annurev.ph.53.030191.001245)

Klein S, Roghani M \& Rifkin DB 1997 Fibroblast growth factors as angiogenesis factors: new insights into their mechanism of action. EXS 79 159-192.

Kopincova J, Puzserova A \& Bernatova I 2011 Biochemical aspects of nitric oxide synthase feedback regulation by nitric oxide. Interdisciplinary Toxicology 4 63-68. (doi:10.2478/v10102-011-0012-z)

Kostyk SK, Kourembanas EL, Medeiros WD, McQuilllan LP, D'Amore PA \& Braunhut SJ 1995 Basic fibroblast growth factor increases nitric synthase production in bovine endothelial cells. American Journal of Physiology 269 H1583-H1589.

Kou R, Greif D \& Michel T 2002 Dephosphorylation of endothelial nitricoxide synthase by vascular endothelial growth factor. Implications for the vascular responses to cyclosporin A. Journal of Biological Chemistry 277 29669-29673. (doi:10.1074/jbc.M204519200)

Kyriakis JM \& Avruch J 1996 Protein kinase cascades activated by stress and inflammatory cytokines. Bioessays 18 567-577. (doi:10.1002/bies. 950180708)
Lang I, Pabst MA, Hiden U, Blaschitz A, Dohr G, Hahn T \& Desoye G 2003 Heterogeneity of microvascular endothelial cells isolated from human term placenta and macrovascular umbilical vein endothelial cells. European Journal of Cell Biology 82 163-173. (doi:10.1078/0171-9335-00306)

Lang I, Schweizer A, Hiden U, Ghaffari-Tabrizi N, Hagendorfer G, Bilban M, Pabst MA, Korgun ET, Dohr G \& Desoye G 2008 Human fetal placental endothelial cells have a mature arterial and a juvenile venous phenotype with adipogenic and osteogenic differentiation potential. Differentiation $\mathbf{7 6}$ 1031-1043. (doi:10.1111/j.1432-0436.2008.00302.x)

Lechward K, Awotunde OS, Swiatek W \& Muszynska G 2001 Protein phosphatase 2A: variety of forms and diversity of functions. Acta Biochimica Polonica 48 921-933.

Lee T, Kim SJ \& Sumpio BE 2003 Role of PP2A in the regulation of p38 MAPK activation in bovine aortic endothelial cells exposed to cyclic strain. Journal of Cellular Physiology 194 349-355. (doi:10.1002/jcp.10211)

Leidi M, Mariotti M \& Maier JA 2010 EDF-1 contributes to the regulation of nitric oxide release in VEGF-treated human endothelial cells. European Journal of Cell Biology 89 654-660. (doi:10.1016/j.ejcb.2010.05.001)

Li Y, Zheng J, Bird IM \& Magness RR 2003 Effects of pulsatile shear stress on nitric oxide production and endothelial cell nitric oxide synthase expression by ovine fetoplacental artery endothelial cells. Biology of Reproduction $\mathbf{6 9}$ 1053-1059. (doi:10.1095/biolreprod.102.013474)

Li Y, Zheng J, Bird IM \& Magness RR 2004 Mechanisms of shear stressinduced eNOS phosphorylation and expression in ovine feto-placental artery endothelial cells. Biology of Reproduction 70 785-796. (doi:10.1095/ biolreprod.103.022293)

Liao Y \& Hung MC 2004 A new role of protein phosphatase 2A in adenoviral E1A protein-mediated sensitization to anticancer drug-induced apoptosis in human breast cancer cells. Cancer Research 64 5938-5942. (doi:10.1158/ 0008-5472.CAN-04-1533)

Liao WX, Feng L, Zhang HH, Zheng J, Moore TR \& Chen DB 2009 Compartmentalizing VEGF-induced ERK2/1 signaling in placental artery endothelial cell caveolae: a paradoxical role of caveolin-1 in placental angiogenesis in vitro. Molecular Endocrinology 23 1428-1444. (doi:10.1210/ me.2008-0475)

Liao WX, Feng L, Zheng J \& Chen DB 2010 Deciphering mechanisms controlling placental artery endothelial cell migration stimulated by vascular endothelial growth factor. Endocrinology 151 3432-3444. (doi:10.1210/en. 2009-1305)

Liu Y, Shepherd EG \& Nelin LD 2007 MAPK phosphatases - regulating the immune response. Nature Reviews. Endocrinology 7 202-212. (doi:10.1038/ nri2035)

Magness RR 1998 Maternal cardiovascular and other physiologic responses to the endocrinology of pregnancy. In Endocrinology of Pregnancy, ch 18, pp 507-539. Ed Fuller BW. Totowa, NJ: Humana Press.

Magness RR \& Zheng J 1996 Circulatory changes during gestation. In Scientific Basis of Pediatric and Perinatal Medicine, 2nd edn, pp 762-772. Eds Gluckman PD \& Heymann MA. London: Edward Arnold Publishers.

Manjunath N, Wu H, Subramanya S \& Shankar P 2009 Lentiviral delivery of short hairpin RNAs. Advanced Drug Delivery Reviews 61 732-745. (doi:10. 1016/j.addr.2009.03.004)

Mata-Greenwood E, Liao WX, Zheng J \& Chen DB 2008 Differential activation of multiple signaling pathways dictates eNOS upregulation by FGF2 but not VEGF in placental artery endothelial cells. Placenta 29 708-717. (doi:10.1016/j.placenta.2008.05.005)

Mata-Greenwood E, Liao WX, Zheng J \& Chen DB 2010 Activation of AP-1 transcription factors differentiates FGF2 and VEGF regulation of endothelial nitric oxide synthase expression in placental artery endothelial cells. Journal of Biological Chemistry 285 17348-17358. (doi:10.1074/jbc. M109.092791)

Matsumoto T, Turesson I, Book M, Gerwins P \& Claesson-Welsh L 2002 p38 MAP kinase negatively regulates endothelial cell survival, proliferation, and differentiation in FGF-2-stimulated angiogenesis. Journal of Cellular Biology 156 149-160. (doi:10.1083/jcb.200103096)

Meschia G 2004 Placental respiratory gas and exchange and fetal oxyenation. In Maternal-Fetal Medicine: Principles and Practice, 5th edn, pp 199-207. Eds Creasy RK, Resnik R, Iams JD. Philadelphia: Elsevier Health Sciences. 
Michell BJ, Griffiths JE, Mitchelhill KI, Rodriguez-Crespo I, Tiganis T, Bozinovski S, de Montellano PO, Kemp BE \& Pearson RB 1999 The Akt kinase signals directly to endothelial nitric oxide synthase. Current Biology 9 845-848. (doi:10.1016/S0960-9822(99)80371-6)

Michell BJ, Chen ZB, Tiganis T, Stapleton D, Katsis F, Power DA, Simi AT \& Kemp BE 2001 Coordinated control of endothelial nitric-oxide synthase phosphorylation by protein kinase C and the cAMP-dependent protein kinase. Journal of Biological Chemistry 276 17625-17628. (doi:10.1074/jbc. C100122200)

Molkentin JD 2004 Calcineurin-NFAT signaling regulates the cardiac hypertrophic response in coordination with the MAPKs. Cardiovascular Research 63 467-475. (doi:10.1016/j.cardiores.2004.01.021)

Morales-Ruiz M, Fulton D, Sowa G, Languino LR, Fujio Y, Walsh K \& Sessa WC 2000 Vascular endothelial growth factor-stimulated actin reorganization and migration of endothelial cells is regulated via the serine/threonine kinase Akt. Circulation Research 86 892-896. (doi:10. 1161/01.RES.86.8.892)

Morris KV 2009 RNA-directed transcriptional gene silencing and activation in human cells. Oligonucleotides 19 299-306. (doi:10.1089/oli.2009.0212)

Murata K, Mills I \& Sumpio BE 1996 Protein phosphatase 2A in stretchinduced endothelial cell proliferation. Journal of Cellular Biochemistry $\mathbf{6 3}$ 311-319. (doi:10.1002/(SICI)1097-4644(19961201)63:3<311::AIDJCB6 $>$ 3.0.CO;2-)

Murohara T, Asahara T, Silver M, Bauters C, Masuda H, Kalka C, Kearney M, Chen D, Symes JF, Fishman MC et al. 1998 Nitric oxide synthase modulates angiogenesis in response to tissue ischemia. Journal of Clinical Investigation 101 2567-2578. (doi:10.1172/JCI1560)

Myatt L 1992 Control of vascular resistance in the human placenta. Placenta 13 329-341. (doi:10.1016/0143-4004(92)90057-Z)

Myatt L, Brockman DE, Eis AL \& Pollock JS 1993 Immunohistochemical localization of nitric oxide synthase in the human placenta. Placenta 14 487-495. (doi:10.1016/S0143-4004(05)80202-4)

Namba T, Koike H, Murakami K, Aoki M, Makino H, Hashiya N, Ogihara T, Kaneda Y, Kohno M \& Morishita R 2003 Angiogenesis induced by endothelial nitric oxide synthase gene through vascular endothelial growth factor expression in a rat hindlimb ischemia model. Circulation 108 2250-2257. (doi:10.1161/01.CIR.0000093190.53478.78)

Noiri E, Hu Y, Bahou WF, Keese CR, Giaever I \& Goligorsky MS 1997 Permissive role of nitric oxide in endothelin-induced migration of endothelial cells. Journal of Biological Chemistry 272 1747-1752. (doi:10. 1074/jbc.272.3.1747)

Osol G \& Mandala M 2009 Maternal uterine vascular remodeling during pregnancy. Physiology 24 58-71. (doi:10.1152/physiol.00033.2008)

Pacher P, Beckman JS \& Liaudet L 2007 Nitric oxide and peroxynitrite in health and disease. Physiological Reviews 87 315-424. (doi:10.1152/physrev. 00029.2006)

Parenti A, Morbidelli L, Cui XL, Douglas JG, Hood JD, Granger HJ, Ledda F \& Ziche M 1998 Nitric oxide is an upstream signal of vascular endothelial growth factor-induced extracellular signal-regulated kinase $1 / 2$ activation in postcapillary endothelium. Journal of Biological Chemistry 273 4220-4226. (doi:10.1074/jbc.273.7.4220)

dela Paz NG \& D'Amore PA 2009 Arterial versus venous endothelial cells. Cell and Tissue Research 335 5-16. (doi:10.1007/s00441-008-0706-5)

Perrino BA, Wilson AJ, Ellison P \& Clapp LH 2002 Substrate selectivity and sensitivity to inhibition by FK506 and cyclosporin A of calcineurin heterodimers composed of the alpha or beta catalytic subunit. European Journal of Biochemistry 269 3540-3548. (doi:10.1046/j.1432-1033.2002. 03040.x)

Pipili-Synetos E, Sakkoula E \& Maragoudakis ME 1993 Nitric oxide is involved in the regulation of angiogenesis. British Journal of Pharmacology 108 855-857.

Powers CJ, McLeskey SW \& Wellstein A 2000 Fibroblast growth factors, their receptors and signaling. Endocrine-Related Cancer 7 165-197. (doi:10.1677/ erc. 0.0070165$)$

Rafiee P, Heidemann J, Ogawa H, Johnson NA, Fisher PJ, Li MS, Otterson MF, Johnson CP \& Binion DG 2004 Cyclosporin A differentially inhibits multiple steps in VEGF induced angiogenesis in human microvascular endothelial cells through altered intracellular signaling. Cell Communication and Signaling 2 3. (doi:10.1186/1478-811X-2-3)

Ravi K, Brennan LA, Levic S, Ross PA \& Black SM 2004 S-nitrosylation of endothelial nitric oxide synthase is associated with monomerization and decreased enzyme activity. PNAS 101 2619-2624. (doi:10.1073/pnas. 0300464101)

Reynolds LP \& Redmer DA 1995 Utero-placental vascular development and placental function. Journal of Animal Science 73 1839-1851.

Reynolds LP, Borowicz PP, Vonnahme KA, Johnson ML, Grazul-Bilska AT, Redmer DA \& Caton JS 2005 Placental angiogenesis in sheep models of compromised pregnancy. Journal of Physiology 565 43-58. (doi:10.1113/ jphysiol.2004.081745)

Rocha SF \& Adams RH 2009 Molecular differentiation and specialization of vascular beds. Angiogenesis 12 139-147. (doi:10.1007/s10456-009-9132-x)

Rosenfeld CR, Morriss FH, Makowski EL, Meschia G \& Battaglia FC 1974 Circulatory changes in the reproductive tissues of ewes during pregnancy. Gynecologic Investigation 5 252-268. (doi:10.1159/000301658)

Rousseau S, Houle F, Landry J \& Huot J 1997 p38 MAP kinase activation by vascular endothelial growth factor mediates actin reorganization and cell migration in human endothelial cells. Oncogene 15 2169-2177. (doi:10. 1038/sj.onc.1201380)

Rousseau S, Houle F, Kotanides H, Witte L, Waltenberger J, Landry J \& Huot J 2000 Vascular endothelial growth factor (VEGF)-driven actin-based motility is mediated by VEGFR 2 and requires concerted activation of stress-activated protein kinase 2 (SAPK2/p38) and geldanamycin-sensitive phosphorylation of focal adhesion kinase. Journal of Biological Chemistry 275 10661-10672. (doi:10.1074/jbc.275.14.10661)

Sa G, Murugesan G, Jaye M, Ivashchenko Y \& Fox PL 1995 Activation of cytosolic phospholipase A2 by basic fibroblast growth factor via a $\mathrm{p} 42$ mitogen-activated protein kinase-dependent phosphorylation pathway in endothelial cells. Journal of Biological Chemistry 270 2360-2366. (doi:10. $1074 /$ jbc.270.5.2360)

Shalaby F, Rossant J, Yamaguchi TP, Gertsenstein M, Wu XF, Breitman ML \& Schuh AC 1995 Failure of blood-island formation and vasculogenesis in Flk-1-deficient mice. Nature 376 62-66. (doi:10.1038/376062a0)

Sheehy AM, Burson MA \& Black SM 1998 Nitric oxide exposure inhibits endothelial NOS activity but not gene expression: a role for superoxide. American Journal of Physiology 274 L833-L841.

Shi Y 2009 Serine/threonine phosphatases: mechanism through structure. Cell 139 468-484. (doi:10.1016/j.cell.2009.10.006)

Silverstein AM, Barrow CA, Davis AJ \& Mumby MC 2002 Actions of PP2A on the MAP kinase pathway and apoptosis are mediated by distinct regulatory subunits. PNAS 99 4221-4226. (doi:10.1073/pnas.072071699)

Sladek SM, Magness RR \& Conrad KP 1997 Nitric oxide and pregnancy. American Journal of Physiology 272 R441-R463.

Song Y, Wang K, Chen DB, Magness RR \& Zheng J 2009 Suppression of protein phosphatase 2 does not affect VEGF- and FGF2-stimulated ovine fetoplacental artery endothelial cell proliferation. Placenta 30 907-913. (doi:10.1016/j.placenta.2009.07.003)

Sontag E 2001 Protein phosphatase 2A: the Trojan Horse of cellular signaling. Cellular Signalling 13 7-16. (doi:10.1016/S0898-6568(00)00123-6)

Souttou B, Raulais D \& Vigny M 2001 Pleiotrophin induces angiogenesis: involvement of the phosphoinositide-3 kinase but not the nitric oxide synthase pathways. Journal of Cellular Physiology 187 59-64. (doi:10.1002/ 1097-4652(2001)9999:9999 <00::AID-JCP1051>3.0.CO;2-F)

Sprague BJ, Phernetton TM, Magness RR \& Chesler NC 2009 The effects of the ovarian cycle and pregnancy on uterine vascular impedance and uterine artery mechanics. European Journal of Obstetrics and Gynecology 144 S184-S191. (doi:10.1016/j.ejogrb.2009.02.041)

Sprague B, Chesler NC \& Magness RR 2010 Shear stress regulation of nitric oxide production in uterine and placental artery endothelial cells: experimental studies and hemodynamic models of shear stresses on endothelial cells. International Journal of Developmental Biology 54 331-339. (doi:10.1387/ijdb.082832bs)

Szukiewicz D, Szewczyk G, Watroba M, Kurowska E \& Maslinski S 2005 Isolated placental vessel response to vascular endothelial growth factor 
and placenta growth factor in normal and growth-restricted pregnancy. Gynecologic and Obstetric Investigation 59 102-107. (doi:10.1159/ 000082622)

Tanaka K, Abe M \& Sato Y 1999 Roles of extracellular signal-regulated kinase $1 / 2$ and $\mathrm{p} 38$ mitogen-activated protein kinase in the signal transduction of basic fibroblast growth factor in endothelial cells during angiogenesis. Japanese Journal of Cancer Research 90 647-654. (doi:10.1111/j.1349-7006. 1999.tb00796.x)

Tsurumi Y, Murohara T, Krasinski K, Chen D, Witzenbichler B, Kearney M, Couffinhal T \& Isner JM 1997 Reciprocal relation between VEGF and NO in the regulation of endothelial integrity. Nature Medicine 3 879-886. (doi:10.1038/nm0897-879)

Tuder RM, Flook BE \& Voelkel NF 1995 Increased gene expression for VEGF and the VEGF receptors KDR/Flk and Flt in lungs exposed to acute or to chronic hypoxia. Modulation of gene expression by nitric oxide. Journal of Clinical Investigation 95 1798-1807. (doi:10.1172/JCI117858)

Ugele B \& Lange F 2001 Isolation of endothelial cells from human placental microvessels: effect of different proteolytic enzymes on releasing endothelial cells from villous tissue. In Vitro Cellular \& Developmental Biology. Animal 37 408-413. (doi:10.1290/1071-2690(2001)037<0408:IOECFH > 2.0. $\mathrm{CO} ; 2)$

Urbich C, Reissner A, Chavakis E, Dernbach E, Haendeler J, Fleming I, Zeiher AM, Kaszkin M \& Dimmeler S 2002 Dephosphorylation of endothelial nitric oxide synthase contributes to the anti-angiogenic effects of endostatin. FASEB Journal 16 706-708. (doi:10.1096/fj.01-0637fje)

Van Kanegan MJ, Adams DG, Wadzinski BE \& Strack S 2005 Distinct protein phosphatase $2 \mathrm{~A}$ heterotrimers modulate growth factor signaling to extracellular signal-regulated kinases and Akt. Journal of Biological Chemistry 280 36029-36036. (doi:10.1074/jbc.M506986200)

Vivanco I \& Sawyers CL 2002 The phosphatidylinositol 3-kinase AKT pathway in human cancer. Nature Reviews. Cancer 2 489-501. (doi:10.1038/ nrc839)

Vonnahme KA, Wilson ME, Li Y, Rupnow HL, Phernetton TM, Ford SP \& Magness RR 2005 Circulating levels of nitric oxide and vascular endothelial growth factor throughout ovine pregnancy. Journal of Physiology 565 101-109. (doi:10.1113/jphysiol.2004.082321)

Wang Y \& Zhao S 2010 Vascular biology of the placenta. In Integrated Systems Physiology: from Molecules to Function to Disease. Eds Granger DN \& Granger J. San Rafael: Morgan \& Claypool Life Sciences. (doi:10.4199/C00016ED 1V01Y201008ISP009)

Wang X, Athayde N \& Trudinger B 2003 A proinflammatory cytokine response is present in the fetal placental vasculature in placental insufficiency. American Journal of Obstetrics and Gynecology 189 1445-1451. (doi:10.1067/S0002-9378(03)00652-5)

Wang K, Song Y, Chen DB \& Zheng J 2008 Protein phosphatase 3 differentially modulates vascular endothelial growth factor and fibroblast growth factor 2-stimulated cell proliferation and signaling in ovine fetoplacental artery endothelial cells. Biology of Reproduction 79 704-710. (doi:10.1095/biolreprod.108.068957)

Wang K, Jiang YZ, Chen DB \& Zheng J 2009 Hypoxia enhances FGF2- and VEGF-stimulated human placental artery endothelial cell proliferation: roles of MAP2K1/2/MAPK3/1 and PI3K/AKT1 pathways. Placenta 30 1045-1051. (doi:10.1016/j.placenta.2009.10.007)

Wen HC, Huang WC, Ali A, Woodgett JR \& Lin WW 2003 Negative regulation of phosphatidylinositol 3-kinase and Akt signaling pathway by PKC. Cellular Signalling 15 37-45. (doi:10.1016/S0898-6568(02)00047-5)

Wilkins BJ \& Molkentin JD 2004 Calcium-calcineurin signaling in the regulation of cardiac hypertrophy. Biochemical and Biophysical Research Communications 322 1178-1191. (doi:10.1016/j.bbrc.2004.07.121)

Williams DJ, Vallance PJ, Neild GH, Spencer JA \& Imms FJ 1997 Nitricoxide mediated vasodilation in human pregnancy. American Journal of Physiology $272 \mathrm{H} 748-\mathrm{H} 752$.

Yashima R, Abe M, Tanaka K, Ueno H, Shitara K, Takenoshita S \& Sato Y 2001 Heterogeneity of the signal transduction pathways for VEGF-induced MAPKs activation in human vascular endothelial cells. Journal of Cellular Physiology 188 201-210. (doi:10.1002/jcp.1107)
Young MR, Kolesiak K \& Meisinger J 2002 Protein phosphatase-2A regulates endothelial cell motility and both the phosphorylation and the stability of focal adhesion complexes. International Journal of Cancer 100 276-282. (doi:10.1002/ijc.10491)

Zarlingo TJ, Eis AL, Brockman DE, Kossenjans W \& Myatt L 1997 Comparative localization of endothelial and inducible nitric oxide synthase isoforms in haemochorial and epitheliochorial placentae. Placenta 18 511-520. (doi:10.1016/0143-4004(77)90004-2)

Zhang R, Wang L, Zhang L, Chen J, Zhu Z, Zhang Z \& Chopp M 2003 Nitric oxide enhances angiogenesis via the synthesis of vascular endothelial growth factor and cGMP after stroke in the rat. Circulation Research 92 308-313. (doi:10.1161/01.RES.0000056757.93432.8C)

Zheng J, Vagnoni KE, Bird IM \& Magness RR 1997 Expression of basic fibroblast growth factor, endothelial mitogenic activity, and angiotensin II type-1 receptors in the ovine placenta during the third trimester of pregnancy. Biology of Reproduction 56 1189-1197. (doi:10.1095/biolreprod56.5.1189)

Zheng J, Bird IM, Melsaether AM \& Magness RR 1999 Activation of the mitogen-activated protein kinase cascade is necessary but not sufficient for bFGF and EGF stimulated expression of endothelial nitric oxide synthase. Endocrinology 140 1399-1407. (doi:10.1210/en.140.3.1399)

Zheng J, Yun L, Weiss AR, Bird IM \& Magness RR 2000 Expression of endothelial and inducible nitric oxide synthase and nitric oxide production in the ovine placental and uterine tissues during late pregnancy. Placenta 21 516-524. (doi:10.1053/plac.1999.0504)

Zheng J, Bird IM, Chen DB \& Magness RR 2005 Angiotensin II regulation of fetoplacental artery endothelial functions. Journal of Physiology 565 59-69. (doi:10.1113/jphysiol.2004.082420)

Zheng J, Wen YX, Austin JL \& Chen DB 2006 Exogenous nitric oxide stimulates cell proliferation via activation of a mitogen activated protein kinase pathway in ovine fetoplacental artery endothelial cells. Biology of Reproduction 74 375-382. (doi:10.1095/biolreprod.105.043190)

Zheng J, Wen YX, Song Y, Wang K, Chen DB \& Magness RR 2008 Activation of multiple signaling pathways is critical for fibroblast growth factor 2- and vascular endothelial growth factor-stimulated ovine fetoplacental endothelial cell proliferation. Biology of Reproduction 78 143-150. (doi:10.1095/biolreprod.107.064477)

Ziche M, Morbidelli L, Masini E, Granger HJ, Geppetti P \& Ledda F 1993 Nitric oxide promotes DNA synthesis and cycle GMP formation in endothelial cells from postcapillary venules. Biochemical and Biophysical Research Communications 192 1198-1203. (doi:10.1006/bbrc.1993.1543)

Ziche M, Morbidelli L, Masini E, Amerini S, Granger HJ, Maggi CA, Geppetti P \& Ledda F 1994 Nitric oxide mediates angiogenesis in vivo and endothelial cell growth and migration in vitro promoted by substance $\mathrm{P}$. Journal of Clinical Investigation 94 2036-2044. (doi:10.1172/JCI117557)

Ziche M, Morbidelli L, Choudhuri R, Zhang HT, Donnini S, Granger HJ \& Bicknell R 1997 a Nitric oxide synthase lies downstream from vascular endothelial growth factor-induced but not basic fibroblast growth factorinduced angiogenesis. Journal of Clinical Investigation 99 2625-2634. (doi:10.1172/JCI119451)

Ziche M, Parenti A, Ledda F, Dell'Era P, Granger HJ, Maggi CA \& Presta M $1997 b$ Nitric oxide promotes proliferation and plasminogen activator production by coronary venular endothelium through endogenous bFGF. Circulation Research 80 845-852. (doi:10.1161/01.RES.80.6.845)

Zubilewicz A, Hecquet C, Jeanny JC, Soubrane G, Courtois Y \& Mascarelli F 2001 Two distinct signalling pathways are involved in FGF2-stimulated proliferation of choriocapillary endothelial cells: a comparative study with VEGF. Oncogene 20 1403-1413. (doi:10.1038/sj.onc.1204231)

\section{Received in final form 10 November 2011} Accepted 21 November 2011 Made available online as an Accepted Preprint 21 November 2011 